\title{
Review on Sesame (Sesamum indicum L.) Breeding in Ethiopia
}

\author{
Feyera Takele Degefa \\ Bako Agricultural Research Center, P. O. Box 03, Bako, West Shewa, Ethiopia
}

\begin{abstract}
Sesame (Sesamum indicum L.) is a self-pollinated diploid species with $2 \mathrm{n}=26$ chromosomes. Sesame improvement research in Ethiopia was started in the late 1960s at Werer Agricultural Research Center. The objective of sesame breeding in Ethiopia is to develop the potential by creating cultivars which meet the demands of the sesame farmers, processor and user. The improvement of sesame has lagged behind due to a lack of research shortage of trained personnel, limited financial support and limited international cooperation. Although Indeterminate flowering nature and shattering of capsules at maturity, insects, pests and diseases, heat and drought, among other things are the major factors for low yields of sesame are seen as the challenges of the crop breeding. Suitability of different agro ecology, availability of genetic resource and diversities, market proximity, mutation breeding and different biotechnology approaches are some opportunities of Sesame breeding in Ethiopia. Application of biotechnology together with conventional breeding methods is a valuable approach for breeding superior varieties in a short period of time.
\end{abstract}

Keywords: diversity, importance, opportunities and Sesame (Sesamum indicum L.)

DOI: $10.7176 / \mathrm{JBAH} / 9-17-07$

Publication date:September $30^{\text {th }} 2019$

\section{Introduction}

Sesame (Sesamum indicum L.), commonly known as simsim, is a member of the order Tub florae and family pedaliaceae. It is a self-pollinated diploid species with $2 n=26$ chromosomes. Sesame is one of the major oilseeds crop in Ethiopia. Increasingly, sesame seed is taking a significant role in the oilseeds sector over the past years and has become the most relevant commodity (Rutes et al., 2015). At international market, the demand for sesame from Ethiopia is high. This indicated that the yield increase of sesame can greatly contribute to the economic development of the country. Ethiopia is considered as the center of origin for sesame and the genetic diversity is high, serving as resources for further improving the crop (Daniel and Parzies, 2011).

Globally, sesame is produced over an area of 9.98 million hectare (mha) and annual production around 5.33 million tons (mt) with average productivity of $554.1 \mathrm{kgha}^{-1}$, whereas, in Africa, $5.76 \mathrm{mha}$ and $3.15 \mathrm{mt}$ of annual production with average productivity of $546.4 \mathrm{kgha}^{-1}$ (FAOSTAT, 2017). However, in Ethiopia sesame is produced over 0.29 mha with annual production of $0.23 \mathrm{mt}$ with average productivity of $787.3 \mathrm{kgha}^{-1}$ (FAOSTAT, 2017). Sesame has been given less attention by the farmers because of poor yield due to non-availability of varieties suitable and adaptable to the diverse agro-climatic conditions (Ashri, 2007).

In Ethiopia, the national average seed yield of sesame is $691 \mathrm{kgha}^{-1}$ (CSA, 2018), which is quite low in contrast with yield potential of the crop up to $2000 \mathrm{kgha}^{-1}$ under experimental stations (Mkamilo and Bedigian, 2007). For these reason, sesame production and extension in Ethiopia is quite limited, particularly because of its low yield. Tadele (2005) stated that one of the major problems facing sesame production in Ethiopia has been growing of inferior genotypes with low yield and poor quality. Similarly, Dagnachew et al. (2011) and Zerihun (2012) reported low productivity of sesame due to limited number of adaptable varieties with tolerance to biotic and abiotic factors.

Sesame yields are highly variable depending upon the growing environment, cultural practices and the type of cultivar. Sesame is a low yielder and worldwide average yields are low (Brigham, 1985). The major constraints in sesame production worldwide are lack of wider adapting cultivars, shattering of capsules at maturity, nonsynchronous maturity, poor stand establishment, lack of fertilizer responses, profuse branching, and low harvest index (Ashri, 1994). Besides this, lack of appropriate storage facilities and mechanical mixtures of different variety seeds has been reported as a problem in Ethiopia. In addition, improvement of sesame has been slow mainly due to lake of adequate research and efficient breeding programs (Ashri, 1998). The research attention that has been given to improve this crop is not comparable with the contribution of this crop in Ethiopian economy. Within this point the objective of this review was:

○ To review status of sesame (Sesamum indicum L.) breeding in Ethiopia

- To review the challenges and opportunities of sesame (Sesamum indicium L.) breeding in Ethiopia

\section{Literature Review}

\section{Origin, Distribution and Botanical Description of Sesame}

Two alternative centres viz., East Africa (Ethiopia) or Asia (Indian Subcontinent or further east or central Asia) have been proposed for its origin. Hiltebrandt (1932) considered Africa as the original home of sesame, since this 
continent hosts high number of wild species. The presence of weedy or wild forms of sesame (S. alatum; $2 \mathrm{n}=26$ and $S$. latifolium, $2 \mathrm{n}=32$ ) in Ethiopia show that it is indigenous and considered as the center of origin for sesame and the genetic diversity is high, serving as resources for further improvement of the crop (Daniel and Parzies, 2011). Domestication of sesame is about 5000 years old were found in archaeological excavations in Harappa (Fuller, 2003).

Sesame has been cultivated for centuries in India, Pakistan, Burma, Indo-China, China, Japan and Africa. In more recent times sesame has been introduced into Mexico, Central America, South America, and the U.S.A (Lalpantluangi and Shah, 2018). Sesame is one of the world's oldest spice and oilseed crop and it is native to tropic and sub-tropic regions. Because of increased export value of this crop, its production area has been extending to places previously not known in sesame production. Nowadays sesame is cultivated from lowland to mid altitudes (300-1700m). Nevertheless, it grows and yields well in altitudes ranging from 650 to 1250 masl (Geremew et al., 2012).

Sesame (Sesamum indicum L.) is a diploid with $2 \mathrm{n}=26$ chromosomes (Morinaga et al., 1929) which belongs to the family of pedaliaceae. The family pedaliaceae has a superior ovary, usually two-celled, which is completely or partially divided by false septa, each compartment having one to several ovules attached to a central placenta. Some cultivars are highly branched, while others grow relatively un-branched. The leaves are variable in size and shape, opposite or occasionally alternate. The genus Sesamum comprises 20 accepted species native to Africa and Asia (Bedigian, 2015), but only S.indicum has been recognized as a cultivated species in the family.

Sesame has been described as a self-pollinated species. However, varying degrees of natural crossing to the extent of 2 to $48 \%$ has been reported (Daniel and Parzies, 2011). Sesame is an herbaceous annual plant requiring 80-130 days to attain physiological maturity. It requires $25{ }^{\circ} \mathrm{C}$ to $27{ }^{\circ} \mathrm{C}$ for rapid germination, initial growth and flower formation while temperature below $18{ }^{\circ} \mathrm{C}$ after germination restricts growth and high temperature $\left(>40{ }^{\circ} \mathrm{C}\right)$ during flowering reduces fertilization. Sesame is very drought resistant/tolerant, by having an extensive root system but it requires adequate moisture for germination and early growth. It is extensively susceptible to waterlogging and heavy continuous rains at all stages of development (Weiss, 1971).

The growth of sesame is indeterminate, that is the plant continues to produce leaves, flowers and capsules as long as weather permits (Weiss, 1971; Bedigian, 2015). Nevertheless, most of the currently cultivated varieties are determinate with uniform and short flowering and capsule ripening periods. Sesame is a broadleaf plant that grows to a height up to 1.5 to 2 meters, depending on the variety and growing conditions (Geremew et al., 2012). Sesame is a broad leaf summer crop similar to cotton, sunflower, soybeans, black eyed peas, Mung bean, or guar. The fruiting form of sesame is a capsule, often called pods. Some varieties have a single capsule per leaf axil and others have triple capsules per leaf axil. Flowering starts about 35-45 days after planting and flowering stops 75-85 days after planting.

\section{Importance of the Sesame crop}

Sesame is the sixth most important oilseed crop in the world after soybean, rapeseed, cottonseed, sunflower and groundnut. India is the world leader in the area and production of sesame (Kante, 2017). In Ethiopia, the production of sesame is both by small and large scale farmers; and it is an important export commodity. Ethiopia is $3^{\text {rd }}$ sesame exporter in the world next to Nigeria and India and sesame is first export (79\%) from oil seeds and $2^{\text {nd }}(20 \%)$ agricultural export next to coffee in Ethiopia (Zerihun, 2012). It is economically the major cash crop for smallholder farmers and a valuable foreign exchange revenue item for different countries economy. After oil extraction, the remaining residues are used as a source of crude protein for cattle feed. In Ethiopia, sesame is used as cash crop, export commodity, raw materials for industries and as source of employment opportunity. Currently, it has becomes the primary export oil crop, playing an important role in the agricultural GDP of the country.

Light colored seeds are considered to yield better quality oil than dark. However, dark colored varieties have high oil content than light colored seed. White-seeded varieties are preferred when roasted and eaten. They also command the market premium over the dark seed (Geremew et al., 2012). Sesame is grown for its seed, and the primary use of the sesame seed is as a source of oil for cooking. Despite its importance, sesame is considered as an orphan crop because it has received very little support from science, industry and policy makers (Chemeda et al., 2014)

The seed is consumed whole in bakeries or pressed for oil extraction. The oil has a composition that provides good health benefits including high levels of unsaturated fatty acids $(80 \%)$ and antioxidants. Beside advantages such as drought tolerance and acceptance of a range of different soils, sesame stimulates a flora of beneficial soil microbes and reduces the nematode populations, particularly the root knot nematodes (Meloidogyne arenaria, Meloidogyne incignita) that attack peanuts and cotton. Sesame is also an excellent soil builder because of the large amounts of root biomass that are left to decay underground after harvest (Pham, 2011).

Sesame contains several notable health-benefiting nutrients, minerals, antioxidants and vitamins that are essential for wellness (Riccio and Rossano, 2015). Sesame oil is unique among vegetable oils due to the presence of natural antioxidants such as sesamin and sesamolin and their derivatives (sesamol and sesaminol), which 
provide a significantly long shelf life and stable characteristic (Brar and Ahuja, 1980). Sesame oil is also used in soaps, paints, perfumes, pharmaceuticals and insecticides. The cake produced after the extraction of oil from unhulled seeds is an excellent protein feed for poultry and ruminants (Pathak et al., 2014).

\section{Sesame Breeding Research in Ethiopia and Achievements}

Sesame improvement research in Ethiopia was started in the late 1960s by Institute of Agricultural Research (IAR) at Werer Agricultural Research Center (WARC) under irrigation with landraces and exotic germplasms. The objective of sesame breeding in Ethiopia is to develop the potential by creating cultivars which meet the demands of the sesame growers, processor and consumer. The improvement aspect was targeted to the higher seed yield and oil content. Ethiopian sesame breeders have come to rely on breeding methods involving the use of collection, introduction, selection (mass and pure line), hybridization (followed by pedigree and bulk method of breeding) and recently induced mutation (Daniel, 2017).

A crossing program was started at Werer Agricultural Research Center since 1983 with the main aim to incorporate high seed and oil yield, drought and disease resistance (bacterial blight), partial-shattering and determinate flowering characters. Subsequent segregating populations were handled using pedigree and bulk methods of breeding (WARC, 2006). Induced mutation program using chemical mutagens is in progress for generation of variability for some important traits such as shattering resistance since sufficient variability in the existing germplasm is lacking (WARC, 2015).

Generally, sesame breeding research in Ethiopia can be divided into three inter -related periods: First period (late 1960s to 1979) dealt with collection, introduction, characterization and evaluation of sesame germplasm for identifying suitable and best adaptable sesame cultivars for the potential areas, sesame breeding relying entirely upon pure-line and/or mass selection from the local germplasm and introduction. Second period (1980-2007) characterized by the incorporation of crossing program into the already pre-existing breeding methods. Third period (2008 to present) marked by the initiation of molecular approaches including analyses of molecular genetic diversity, development of molecular markers and initiation of induced mutation techniques particularly for pod shattering (Daniel and Parzies, 2011; Woldesenbet, et al., 2015)

There are several achievements of sesame varieties released in Ethiopia. Some of them are under production and trial for various agronomic parameters under different climatic and soil conditions. They are differently stable for their oil and/or seed at different agro ecologies (Chemeda et al., 2014). There is some improved varieties of sesame released in Ethiopia at different place and time. Here below is some varieties released from 2010 up to 2017 by different regional and national research centers and Haramaya University in Ethiopia (Table 1).

Table 1. Some improved varieties of sesame released by the different regional and national research centers and Haromaya University from 2010 to 2017

\begin{tabular}{|c|c|c|c|c|c|c|c|c|}
\hline \multirow[t]{2}{*}{$\overline{\text { Varietal name }}$} & \multirow[t]{2}{*}{$\begin{array}{l}\text { Year of } \\
\text { release }\end{array}$} & \multirow[t]{2}{*}{ Pedigree name } & \multirow[t]{2}{*}{$\begin{array}{l}\text { Altitude } \\
\text { (m.a.s.1) }\end{array}$} & \multicolumn{2}{|c|}{$\begin{array}{c}\text { Average grain yield } \\
(\mathrm{kg} / \mathrm{ha})\end{array}$} & \multirow[t]{2}{*}{$\begin{array}{l}\text { Oil content } \\
(\%)\end{array}$} & \multirow[t]{2}{*}{$\begin{array}{l}\text { Seed } \\
\text { color }\end{array}$} & \multirow[t]{2}{*}{ Maintainer/released } \\
\hline & & & & On farm & On-station & & & \\
\hline Obsa & 2010 & EW004 & $1250-1650$ & 868.8 & 1069 & 51.55 & white - tan & Bako ARC \\
\hline Dicho & 2010 & EW015 & $1250-1650$ & 810.6 & 1063 & 53.8 & White & Bako ARC \\
\hline Barsan & 2010 & ACC-00016 & $500-700$ & - & 960 irrigate & 45.9 & Brown & Gode ARC \\
\hline Lidan & 2010 & ACC-00044 (2) & $500-700$ & - & 1080irrigat & 46.9 & Brown & Gode ARC \\
\hline Humera-1 & 2011 & ACC. 038 sel. 1 & $600-1100$ & - & $590-900$ & 54.56 & White & Humara ARC \\
\hline Setit-1 & 2011 & col sel p\#1 & $600-800$ & - & $620-1000$ & 52.54 & White & Humara ARC \\
\hline ACC 00047 & 2013 & ACC 00047 & - & - & $700-800$ & 50.4 & White & Sirinka ARC \\
\hline Chalasa & 2013 & EW023(2) & $1350-1650$ & $975-1200$ & $10.5-1480$ & 51 & light white & Bako ARC \\
\hline Dangur & 2015 & EW013(8) & - & - & 750 & 56.7 & Gray & Pawe ARC \\
\hline Benishangul-1 & 2016 & WW-001(6) & $740-1280$ & 400 & $435-836$ & 54.1 & White & Humara and Asosa ARC \\
\hline Setit-2 & 2016 & $\mathrm{~J}-03$ & $600-1028$ & 800 & 913 & 53.77 & White & Humara ARC \\
\hline Gonder-1 & 2016 & Acc.ba002 & $760-1022$ & - & $500-900$ & 50 & White & Gonder ARC \\
\hline $\mathrm{BaHaNecho}$ & 2016 & Acc-EW-012(5) & $560-1650$ & $800-1200$ & 1200 & 52 & White & Haramaya University \\
\hline BaHaZeyit & 2016 & (Acc-EW-023(1) & $560-1650$ & $1000-1300$ & 1300 & 56 & light gray & Haramaya University \\
\hline Waliin & 2017 & BG004-1 & $1250-1450$ & $950-1100$ & $1000-1380$ & - & light white & Bako ARC \\
\hline
\end{tabular}

Source: MoARD, crop variety register book 2010- 2017

\section{Breeding Methods Used in Sesame}

Conventional breeding

Conventional breeding is under the control of human for choice of parental lines, and selection of their offspring 
to direct the evolution process for crop production according to their desires. Sesame is predominantly regarded as a self-pollinated plant and low percentages of cross pollination also reported due to insects (Ashri, 2007). Development of sesame varieties with desirable characters is achieved through pedigree selection from segregating generations of different crosses. In conventional plant breeding these traits are manipulated to get desired genetic combination through various procedures. Since seed yield is a polygenic character, it is essential to identify yieldcontributing attributes for selecting high-yielding sesame cultivars. Various physiological traits are useful for determining selection criteria including higher number of capsules, branching and biomass, harvest index, which exhibit significantly positive correlation with seed yield in sesame (Sarwar and Hussain, 2010).

Evaluation and consequent selection of improved lines are the first step in breeding process that largely depends on the knowledge of plant genetic diversity and heritability. Selection (pure line selection and mass selection) is regarded as the most ancient and basic procedure in plant breeding in which desired plants are selected from genetically variable population. These lines are evaluated against existing commercial varieties for yield and other traits for making justified plant selection. Information about relationship between yield and yieldcontributing attributes is very important for a successful breeding program (Ganesh and Sakila, 1999). Plant selection with appropriate sesame variety is essential for increasing seed yield and developing unique sesame varieties. It is considered that breeding based on additively controlled characters helps improving sesame yield (Khan et al., 2007).

In conventional plant breeding, hybridization is the most frequently used technique for sesame yield improvement. It helps to combine the desirable traits from different plant lines into a single plant through cross pollination. Desired traits such as disease resistance and improved oil quality can be transferred from wild relatives of a crop species to the cultivated forms. Heritability estimates and combining ability studies assist in predicting genetic improvement of different types and are useful in hybrid selection program. In sesame, emasculation is the simplest and most commonly used technique for producing F1 hybrids through cross pollination.

\section{Mutation breeding}

Mutation breeding involves induction of new genetic variability through spontaneous or artificial mutagens (chemicals or physical). It minimizes our dependence on the use of wild species or species from other cultivars. Induced mutants are evaluated and selected for desired traits. However, development of large number of mutants with undesirable traits limits its wide application in the breeding programs. Mutagenic techniques are successfully employed in sesame to induce genetic variability. Applications of appropriate doses of physical mutagen or concentration of chemical mutagen are important to get adequate mutations that could benefit sesame breeding program. Researchers at FAO have initiated coordinated research project for genetic improvement in sesame, and developed 142 mutants having agronomically useful characters by using both physical and chemical mutagens and devised method for mutation breeding for sesame (Van, 2001).

Sesame mutants have been selected for desirable traits of higher yield and quality (Wongyai et al., 2001), improved plant architecture (Cagirgan, 2006), seed retention, larger seed size and seed color (Hoballah, 2001). Indeterminate sesame habit is a challenge for sesame breeders, and mutagenic breeding approach is applied to solve this problem (Cagirgan, 2006). A spontaneous indehiscent mutant "id" was discovered in 1942 in Venezuela by Langham (1946). However, due to its low yield and other undesirable side effects it was not used in commercial varieties.

\section{Molecular breeding}

Shortcomings in the conventional breeding (sexual reproduction) are overcome by genetic engineering techniques that introduces desirable genes directly into the target crop making gene pool unbounded. Only desirable traits are improved in this method, therefore, large populations and multiple generations are not required for selection of plants. Likewise, these techniques also have certain drawbacks; only simple and monogenic traits are transferred most of the time, they are relatively expensive and technically demanding and they are controlled by government organizations. Various innovative approaches are used for sesame breeding viz., in vitro culture, genetic transformation and molecular breeding. Marker-assisted selection (MAS) process has revolutionized plant breeding disciplines by increasing selection efficiency at early stages of development and characterization in later generations (Cahill and Schmidt 2004).

The MAS program has been widely applied tool in commercial crop breeding and product development in a variety of agriculturally important economic crops, including cereal, oilseeds, vegetables and ornamentals. Similar marker assisted characterization of sesame varieties for conservation and improvement has been tested (Woldesenbet, et al., 2015). The rich genetic variability in Ethiopia will have fundamental use in enhancing the genetic variability and sesame cultivation across the various agro ecologies. Molecular breeding will have the front lead to conventional breeding for improved sesame production in Ethiopia and enhancing crop productivity to utilize the crop potential under improved agronomic practices (Abadi, 2018) 


\section{Major challenges of sesame breeding}

The improvement of sesame has left behind due to a lack of research, shortage of trained personnel, limited financial support, limited international cooperation and biotic and abiotic factors. The crop is not dealt with by any of Consultative Group on International Agricultural Research (CGIAR) centers (Daniel, 2017). However, the crop has high importance as it adapt harsh situations where other crops cannot tolerate (MoAR et al., 2015). In Ethiopia the mean yield of sesame is very low. However, there is a great potential to be exploited in sesame production. Additionally, indeterminate flowering nature and shattering of capsules at maturity, insects, pests and diseases, heat and drought, among other things are the major factors for low yields of sesame have seen as the challenges of the sesame improvement.

Figure 1: major challenges of sesame breeding

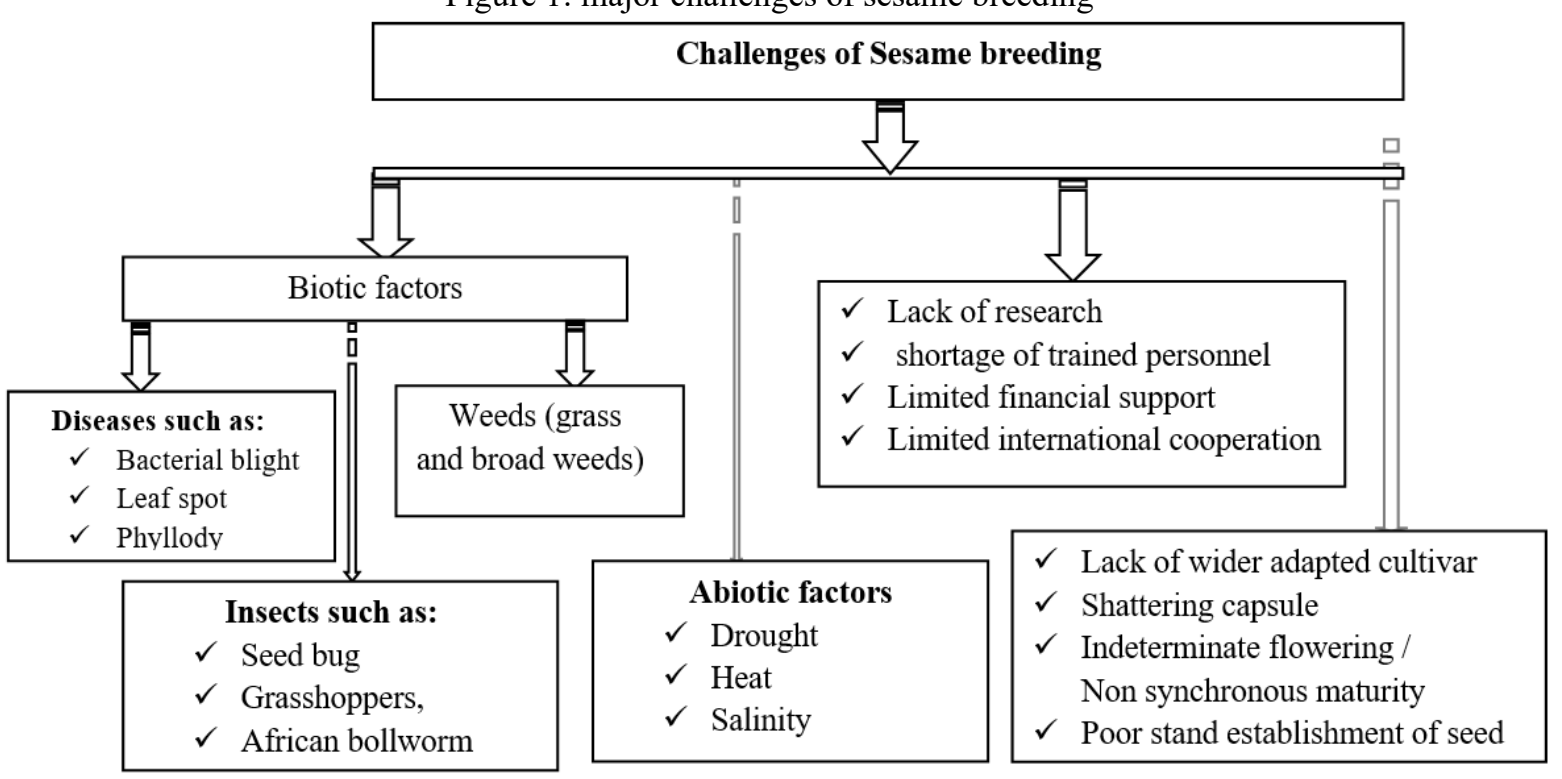

\section{Major opportunities of sesame breeding in Ethiopia}

\section{Sesame genetic resource and diversity}

Ethiopia is one of the centers of biodiversity for several oilseeds (sesame seed, Niger seed, mustard seed, pumpkin seed, sunflower, rape seed, castor seeds, ground nuts) which can be considered as specialty high value seeds on the international market (Mohammed et al.,2015). Ethiopia is considered as one of the richest genetic resource centers of sesame in the world. The presence of wide altitudinal range (120 m to $4600 \mathrm{~m}$ a.s.1.), substantial temperature, edaphic and rainfall differences created a wide range of agro ecological conditions that provided sustainable environments for a broad range of life forms. Next to coffee, sesame seed is the second largest export crop for Ethiopia and it is an important cash crop as it has an excellent demand in the international market and is utilized by domestic oil production

Hiltebrandt (1932) considered Africa as the original home of sesame, since this continent hosts high number of wild species. The presence of weedy or wild forms of sesame (S. alatum; $2 \mathrm{n}=26$ and $S$. latifolium, $2 \mathrm{n}=32)$ in Ethiopia show that it is indigenous and considered as the center of origin for sesame and the genetic diversity is high, serving as resources for further improving the crop (Daniel and Parzies , 2011).

Genetic diversity studies were done by different researchers on Ethiopian sesame collections in different times (Endale et al., 2011; Alemu et al., 2013, Desawi et al., 2014, Gadisa et al., 2014; Gadisa et al., 2015) and the researchers reported that phenotypic and genotypic variations have been detected in the specific populations studied. Endale et al. (2011) studied 50 populations of Ethiopian sesame using SSR markers and ample amount of genetic variations were reported. Alemu et al. (2013) reported that significant genetic variation were detected using ISSR markers among six farmers' varieties of sesame from Northern Ethiopia indicating that Ethiopia has ample genetic resources of sesame which could be utilized for improvement programs.

\section{Summary and Conclusion}

Sesame (Sesamum indicum L.) is a self-pollinated diploid species with $2 \mathrm{n}=26$ chromosomes. The presence of weedy or wild forms of sesame ( $S$. alatum; $2 \mathrm{n}=26$ and $S$. latifolium, $2 \mathrm{n}=32$ ) in Ethiopia show that it is indigenous to this country. Sesame is grown in Ethiopia for the purpose of home consumption and as cash crop. Sesame improvement work has been started by Werer Agricultural Research Center of Ethiopia. The objective of sesame breeding in Ethiopia is to develop the potential by creating cultivars which meet the demands of the sesame farmers and others. Generally, Sesame breeding research in Ethiopia have been divided into three inter -related periods: 
First period (late 1960s to 1979) dealt with collection, introduction, characterization and evaluation of sesame germplasm, Second period (1980-2007) characterized by the incorporation of crossing program into the already pre-existing breeding methods and Third period (2008 to present) marked by the initiation of molecular approaches including analyses of molecular genetic diversity, development of molecular markers and initiation of induced mutation techniques particularly for pod shattering

The improvement of sesame has lagged after other crops due to a lack of research shortage of trained personnel, limited financial support and limited international cooperation. Many production constraints delayed considerable yield improvement such as indeterminate flowering nature and shattering of capsules at maturity and other biotic and a biotic factors. There are different opportunities which maximize the breeding of sesame in Ethiopia such as suitability of different agro ecology, availability of genetic resource and diversities, market proximity and different biotechnology approaches. Application of biotechnology along with conventional breeding methods is a useful approach for breeding superior varieties in a short time. In addition, the construction of molecular genetics maps, tagging-desired traits for marker-assisted selection and positional cloning could be more reliable tools in genetic studies than morphological traits to maximize sesame breeding accordingly.

\section{References}

Alemu A., Petros, Y. and Tesfaye, K. (2013). Genetic distance of sesame (Sesamum indicum L.) cultivars and varieties from Northwestern Ethiopia using Inter Simple Sequence Repeat Markers. East African Journal of Sciences, 7:31-40.

Ashri, A. (1994). Genetic resources of sesame: Present and future perspectives. In: Arora, R.K. and Riley, K.W. (Eds). Sesame Biodiversity in Asia Conservation, Evaluation and Improvement, IPGRI Office for South Asia, New Delhi, India. Pp. 25-39.

Ashri, A. and Singh, R.J., 2007. Sesame (Sesamum indicum L.). Genetic Resources, Chromosome Engineering and Crop Improvement: Oilseed Crops, 4:231-280

ASHRI, A. Report on FAO/IAEA expert consultation on breeding improved sesame cultivars, Vienna, September 1987, FAO/AGP, Rome (1987).

Ashri, A., 1998. Sesame breeding. Plant Breed. Rev. 16, 179-228.

Bedigian, D., 2015. Systematics and evolution in Sesamum L. (Pedaliaceae), part 1: Evidence regarding the origin of sesame and its closest relatives. Webbia, 70(1):1-42

Brar, G.S. and Ahuja, K.L., 1980. Sesame: its culture, genetics, breeding and biochemistry. Annual reviews of plant sciences

Cahill, D.J. and Schmidt, D.H., 2004, September. Use of marker assisted selection in a product development breeding program. In New Directions for a Diverse Planet". Proceedings of the 4th International Crop Science Congress, Brisbane, Australia (pp. 1-9).

Chemeda, D., Amsalu, A., Hamtamu, Z. and Adugna, W., 2014. Association of stability parameters and yield stability of sesame (Sesamum indicum L.) genotypes in Western Ethiopia. East African Journal of Sciences, 8(2): $125-134$

CSA (Central Statistical Agency). 2018. Agricultural Sample Survey for the 2017/2018 crop season .Volume I. Report on Area and Production of Major crops for Private Peasant Holdings (Meher Season). Statistical Bulletin 278. FDRE/CSA, Addis Ababa, Ethiopia

Dagnachew, L., Girma, M., Abeya, T., Chemeda, D., Aschalew, S., Kasa, M., Zerihun, A., Teshome, B., Shiferaw, T. and Abdulaziz, T., 2011. Progress and prospects of sesame breeding in Western Ethiopia. Oilseeds: Engine for Ethiopian Economic Development. EIAR, Addis Ababa, Ethiopia, pp.129-140

Daniel E.G., 2017. Sesame (Sesamum indicum L.)Breeding in Ethiopia. International Journal of Novel Research in Life Sciences. 4(1):1-11

Daniel E.G., and Parzies, H.K., 2011. Genetic variability among landraces of sesame in Ethiopia. African Crop Science Journal, 19(1):1-13

Desawi H.T, Sentayehu A.K, and Daniel E.G, 2014. Assessment of genetic variability, genetic advance, correlation and path analysis for morphological traits in sesame genotypes. Asian Journal of Agricultural Research, 8(4):181-194

FAOSTAT.2017. Food and Agriculture of the United Nations. (http://faostat.fao.org) (Accessed on March 22, 2019)

Fuller, D.Q., 2003.Further evidence on the prehistory of sesame. Asian Agri-History, 7(2):127-137

Gadisa, H., Negash, G. and Zerihun, J., 2015. Genetic variability, heritability and genetic advance for the phenotypic traits in sesame (Sesamum indicum L.) populations from Ethiopia. Science, Technology and Arts Research Journal, 4(1): 20-26

Geremew, T., Adugna, W., Muez, B. and Hagos, T., 2012. Sesame production manual. EIAR and Embassy of the Kingdom of the Netherlands, pp.1-34

Girmay, A.B., 2018. Sesame production, challenges and opportunities in Ethiopia. Agricultural Research and 
Technology. 15(15)

Hiltebrandt V.M., 1932. Sesame (Sesamum indicum L.). Bull. Appl. Bot. Plant Breed. 9:

Hoballah AA (2001) Selection and agronomic evaluation of induced mutant lines of sesame. In: Sesame improvement by induced mutations, IAEA-TECDOC-1195. IAEA, Vienna, pp 137-150

Kafiriti E, Deckers J (2001) Sesame (Sesamum indicum L.). In: RH Raemaekers, Crop Production in Tropical Africa (pp. 797-804). Brussels, Belgium: Directorate General for Inernational Co-operation

Kante, S., 2017. Studies on genetic diversity, patha anlysis and correlation in sesame (Sesamum indicum l.) (Doctoral dissertation, Vasantrao Naik Marathwada Krishi Vidyapeeth, Parbhani).

Lalpantluangi, P.C. and Shah, P., 2018. Character association and path coefficient analysis in sesame (Sesamum indicum L.) genotypes under foothill condition of Nagaland. The Pharma Innovation, 7(5b):82

Langham, D.R., Riney, J., Smith, G. and Wiemers, T. 2008. Sesame harvest guide. Www.sesaco.net. Accessed on February 2016

Mkamilo, G.S. and Bedigian, D., 2007. Sesamum indicum L. Vegetable Oils. Plant Resources of Tropical Africa, 14:153-158

MoARD (Ministry of Agriculture and Rural Development), 2010-2017. Crop Variety Register Book. Animal and Plant health Regulatory Directorate. Addis Abeba, Ethiopia.

Mohammed A., Firew M., Amsalu, A. and Mandefro, N., 2015. Genetic variability and association of traits in midaltitude sesame (Sesamum indicum L.) germplasm of Ethiopia. American Journal of Experimental Agriculture, 9(3):1-14

Pathak, N., Rai, A.K., Kumari, R., Thapa, A. and Bhat, K.V., 2014. Sesame crop: an underexploited oilseed holds tremendous potential for enhanced food value. Agricultural Sciences, 5(06):519

Pham, T., 2011. Analyses of genetic diversity and desirable traits in sesame (Sesamum indicum L., Pedaliaceae): implication for breeding and conservation Vol. 2011, No. 42).

Rao, K.R., Kishor, P.B.K. and Vaidyanath, K., 2002. Biotechnology of sesame-an oil seed crop. Plant Cell Biotechnol Mol Biol, 3, pp.101-110.

Riccio, P. and Rossano, R., 2015. Nutrition facts in multiple sclerosis. ASN neuro, 7(1), p.1759091414568185.

Tadele A., 2005. Sesame (Sesamum indicum L.) Research in Ethiopia: A review of past work and potential and future prospects. Werer Agricultural Research Center. EIAR, Addis Ababa, Ethiopia

Van den Bos, W. and Zee, C.J., 2016. Sesame Production Manual. Addis Ababa, Ethiopia

Van Z. L., 2001. Sesame improvement by induced mutations. Plant Breeding and Genetics Section, Joint FAO/IAEA Division of Nuclear Techniques, in Food and Agriculture, International Atomic Energy Agency, Vienna (Austria), pp.2-12.

WARC (Werer Agricultural Research Center), 2006. Progress report. Lowland Oil crops Research Division, Werer, Ethiopia

WARC (Werer Agricultural Research Center), 2015. Progress report. Lowland Oil crops Research Division, Werer, Ethiopia

Wei, L.B., Zhang, H.Y., Zheng, Y.Z., Miao, H.M., Zhang, T.Z. and Guo, W.Z., 2009. A genetic linkage map construction for sesame (Sesamum indicum L.). Genes \& genomics, 31(2), pp.199-208.

Woldesenbet, D.T., Tesfaye, K. and Bekele, E., 2015. Genetic diversity of sesame germplasm collection (Sesamum indicum L.): implication for conservation, improvement and use. International Journal of Biotechnology and Molecular Biology Research, 6(2):7-18

Wongyai W, Saengkaewsook W, Veerawudh J (2001) Sesame mutation induction: improvement of non-shattering capsule by using gamma rays and EMS. In: Sesame improvement by induced mutations, IAEA-TECDOC1195. IAEA, Vienna, pp 71-78

Yadav, M., Chaudhary, D., Sainger, M. and Jaiwal, P.K., 2010. Agrobacterium tumefaciens-mediated genetic transformation of sesame (Sesamum indicum L.). Plant Cell, Tissue and Organ Culture (PCTOC), 103(3), pp.377-386.

Zerihun, J., 2012. Sesame (Sesame indicum L.) crop production in Ethiopia: Trends, challenges and future prospects. Science, Technology and Arts Research Journal, 1(3):01-07 